Jurnal Progres Ekonomi Pembangunan (JPEP)

Volume 4, Nomor 1 (2), Tahun 2019

Page: $36-44$

http://ojs.uho.ac.id/index.php/JPEP

\title{
PENGARUH PENDIDIKAN DAN PELATIHAN, PENGALAMAN KERJA DAN DISIPLIN KERJATERHADAP KINERJA PENGELOLA KEUANGAN DI UNIVERSITAS HALU OLEO
}

\author{
Sri Wahyuni Saleh \\ Program Pascasarjana Universitas Halu Oleo, Kendari \\ Email: yhuesriwahyuni@gmail.com \\ Andi Basru Wawo \\ Universitas Halu Oleo, Kendari \\ Husin \\ Universitas Halu Oleo, Kendari
}

\begin{abstract}
This study aims to find out and analyze the Effect of Education and Training, Work Experience and Work Discipline on Financial Management Performance at Halu Oleo University. Respondents in this study were all employees who served as financial managers at Halu Oleo University. The total respondents were 106 people. Data analysis used in this study is multiple linear regression analysis techniques that are processed through SPSS version 23.0 for Windows software.

The results of this study indicate that education and training have $t$ ( $t$-sig) of 0,000 which means that education and training have a positive and significant effect on the performance of financial managers, work experience has $t$ ( $t$-sig) of 0.118 which means that work experience has no effect and is not significant on performance financial managers, work discipline has $t$ ( $t$-sig) of 0.031 which means that work discipline has a positive and significant effect on the performance of financial managers. The conclusions in this study are education and training, work experience and work discipline simultaneously have a significant effect on the performance of financial managers. Education and training have a significant effect on the performance of financial managers, work experience has no effect and is not significant on the performance of financial managers and work discipline has a significant effect on the performance of financial managers in
\end{abstract}

Keywords: Education and Training, Work Experience, Work Discipline, Financial Managers.

\section{PENDAHULUAN}

Peningkatan mutu pendidikan bukanlah hal yang mudah, karena tidak hanya berkaitan dengan permasalahan teknis, tetapi mencakup berbagai persoalan yang kompleks, baik yang berkaitan dengan perencanaan, pendanaan, efisiensi dan efektifitas penyelenggaraan sistem pendidikan. Untuk mewujudkan pendidikan yang berkualitas, perlu adanya pengelolaan secara menyeluruh dan profesional terhadap sumber daya yang ada dalam perguruan tinggi. Salah satu sumber daya yang perlu dikelola dengan baik dalam perguruan tinggi adalah masalah keuangan.

Dalam peningkatan mutu perguruan tinggi terutama pada aspek keuangan yang menjadi tujuan utama yaitu pengelolaan keuangan yang sehat, transparan dan akuntabel. Transparan dan akuntabel harus selalu dijunjung dalam sistem pengelolaan keuangan dengan tetap berprinsip pada kaidah-kaidah akuntansi.

Salah satu sistem dalam pengelolaan keuangan bagi perguruan tinggi yaitu Badan Layanan Umum (BLU). BLU diatur dalam Peraturan Pemerintah Nomor 23 Tahun 2005 tentang Pengelolaan Keuangan BLU sebagaimana diubah dengan Peraturan Pemerintah Nomor 74 Tahun 2012.

Pengelola keuangan dalam menjalankan amanahnya harus sesuai peraturan yang ditetapkan dalam peraturan Keuangan Negara dan 
Jurnal Progres Ekonomi Pembangunan (JPEP)

Volume 4, Nomor 1 (2), Tahun 2019

Page: $36-44$

http://ojs.uho.ac.id/index.php/JPEP

peraturan Perbendaharaan Negara dan apabila tidak diikuti sesuai dengan peraturan yang berlaku maka dapat menghambat aktivitas akademik. Jika aktivitas - aktivitas tersebut terhambat maka akan mempengaruhi kinerja instansi. Oleh karena itu, organisasi maupun instansi membutuhkan sumber daya manusia dalam hal ini yaitu pegawai yang mengelola keuangan serta mempunyai kinerja (Job Perfomance) yang tinggi.

Keberhasilan dan kesuksesan kinerja suatu organisasi ditentukan oleh kualitas sumber daya manusianya. Kinerja (Performance) adalah gambaran mengenai tingkat pencapaian pelaksanaan suatu kegiatan/program/kebijakan dalam mewujudkan sasaran, tujuan, misi dan visi organisasi yang tertuang dalam perencanaan strategis suatu organisasi. Kriteria keberhasilan ini berupa tujuan-tujuan atau target-target tertentu yang hendak dicapai. Tanpa ada tujuan atau target, kinerja seseorang atau organisasi tidak mungkin dapat diketahui karena tidak ada tolak ukurnya.

Kinerja pengelola keuangan merupakan tolak ukur dalam pencapaian sasaran ataupun peningkatan mutu dari suatu kegiatan dalam Perguruan Tinggi Negeri sehubungan dengan penggunaan dana sesuai dengan kuantitas dan kualitas terukur dengan menggunakan prinsip efisiensi dan efektifitas. Mengingat Perguruan Tinggi Negeri sebagai bagian dari lembaga pelayanan publik yang diselenggarakan oleh Pemerintah, maka para pengelola keuangannya yang menduduki jabatan struktural senantiasa dituntut untuk menunjukkan kinerja yang baik. Seiring dengan perkembangan tuntutan dan tanggung jawab dalam menjalankan tugas dan wewenangnya sebagai pengelola keuangan harus dapat mengembangkan dan meningkatkan kinerjanya.

Universitas Halu Oleo (UHO) merupakan bagian dari organisasi publik yang menyediakan pelayanan untuk penyelenggaraan pendidikan perguruan tinggi. UHO sebagai entitas dalam Direktorat Jenderal Pendidikan Tinggi otomatis mengikuti paradigma baru terhadap perubahan pengelolaan perguruan tinggi yang telah ditetapkan sesuai dengan Rencana Strategis UHO.
Salah satu perubahan yang mendasar dalam pengelolaan perguruan tinggi adalah sistem perencanaan dan pengelolaan keuangan. Model perencanaan dan penganggaran UHO lebih dititik beratkan pada upaya pencapaian visi dan misi dengan tetap berlandaskan pada pola perencanaan dan penganggaran secara nasional yang menjunjung tinggi transparansi dan akuntabilitas. Perubahan sistem perencanaan kegiatan UHO sebagai universitas yang menerapkan sistem pengelolaan keuangan dari pola Pendapatan Negara Bukan Pajak (PNBP) menjadi pola pengelolaan menurut aturan BLU sesuai dengan Surat Keputusan Menteri Keuangan RI Nomor:32/KMK/2010 tanggal 26 Januari 2010.

Berdasarkan Peraturan Menteri Dalam Negeri No. 61 Tahun 2007 tentang Pedoman Teknis Pengelolaan Keuangan Badan Layanan Umum Daerah "Setiap semesteran dan tahunan BLU wajib menyusun dan menyampaikan laporan keuangan lengkap kepada PPKD untuk dikonsolidasikan ke dalam laporan keuangan pemerintah daerah, paling lambat 2 (dua) bulan setelah periode pelaporan berakhir. Sedangkan fenomena yang terjadi pada UHO dalam menyampaikan laporan keuangan 2016 masih belum mengikuti peraturan. Kemudian berdasarkan LAKIP UHO, 2017 Walaupun capaian kinerja mencapai sebesar $99,11 \%$ tahun 2016 mendapatkan kategori memuaskan dan sangat baik, namun masih banyak permasalahan yang di hadapi oleh UHO yang mendesak harus diselesaikan, seperti peningkatan akreditasi program dan institusi, penyusunan kurikulum bagi fakultas baru, peningkatan sarana prasarana pendidikan, peningkatan SDM dan disiplin kerja, peningkatan karakter peserta didik, peningkatan budaya kesejawatan untuk mendukung peningkatan kinerja PNS dalam lingkungan UHO.

Penelitian ini menarik untuk dilakukan karena fenomena menunjukkan bahwa dalam menjalankan fungsi pengelola keuangan seyogyanya diserahkan kepada pegawai yang memiliki latarbelakang pendidikan ekonomi atau akuntansi sehingga dalam pelaksanaan tugas tidak menemui hambatan. Namun kenyataannya adalah penempatan pegawai terutama pada jabatan struktural sebagai pengelola keuangan yang 
Jurnal Progres Ekonomi Pembangunan (JPEP)

Volume 4, Nomor 1 (2), Tahun 2019

Page: $36-44$

e-ISSN: 2052-5171

http://ojs.uho.ac.id/index.php/JPEP

sebagian besar yakni $70 \%$ atau 74 orang memiliki latarbelakang pendidikan bukan di bidang ekonomi ataupun akuntansi. Pengelola keuangan memiliki sumber daya manusia sebanyak 105 orang yang terdiri dari 43unit kerja dalam penelitian ini diharapkan mampu membantu manajemen dalam meningkatkan kinerja pengelola keuangan. Disamping itu, dilakukan pembenahan sistem dan peraturan kerja untuk meningkatkan disiplin kerja pegawai, seperti pemberlakukan absensi melalui sidik jari pada

Tabel 1

Data Pendidikan dan Kehadiran Pengelola Keuangan UHO Tahun 2016

\begin{tabular}{|c|c|c|c|c|c|}
\hline \multirow{2}{*}{ No } & \multirow{2}{*}{ Unit Kerja } & \multicolumn{2}{|c|}{ Pendidikan } & \multirow{2}{*}{ Jumlah } & \multirow{2}{*}{$\begin{array}{l}\text { Persentase } \\
\text { Kehadiran }\end{array}$} \\
\hline & & Akuntansi & Non Akuntansi & & \\
\hline 1 & Bendahara & 9 & 31 & 40 & $86,90 \%$ \\
\hline 2 & Pengelola Teknis & 22 & 43 & 65 & $90,84 \%$ \\
\hline & Jumlah & 31 & 74 & 105 & $89,34 \%$ \\
\hline
\end{tabular}

Sumber data : Data diolah (2017)

Tabel 1menunjukan bahwa pendidikan pengelola keuangan UHO mayoritas pendidikan non akuntansi yaitu berjumlah 74 orang sedangkan latarbelakang pendidikan akuntansi hanya 31orang. Serta persentase kehadiran menunjukan bahwa rata-rata kehadiran pengelola keuangan UHO adalah $89,34 \%$. Unit kerja yang memiliki kehadiran yang tinggi adalah pengelola teknis yaitu dengan persentase kehadiran 90,84\% sedangkan unit kerja yang memiliki tingkat kehadiran yang rendah adalah yaitu bendahara dengan persentase kehadiran $86,90 \%$.

Beberapa faktor yang mempengaruhi kinerja pengelola keuangan, diantaranya adalah pendidikan dan pelatihan, pengalamana kerja dan disipin kerja. Rachmawati (2008:13) menjelaskan pendidikan dan pelatihan bagi pegawaisebuah proses mengajarkanpengetahuan, keahlian tertentu, sikap danmampu melaksanakan tanggung jawab yangdiberikan. Kegiatan pendidikan diberikanuntuk membantu pegawai mengembangkankapasitasnya/pengetahuan yang dimilikinyasehingga pegawai dapat bekerja lebih baikdalam meningkatkan kinerja untuk mencapaitujuan dari organisasi dimasa yang akandatang. Pendidikan dan pelatihan menjadi begitu penting untuk diterapkan dalam mengelola keuangan karena akan memberi pengaruh pada mesin, pelaksanaan apel pagi dan apel sore untuk memastikan pegawai agar benar-benar selalu berada di ruang kerjanya pada saat jam kerja. Hal ini dilakukan agar UHO memiliki sumber daya manusia yang handal, profesional dan berkualifikasi sehingga dapat dan mampu beradaptasi dengan tuntuntan zaman serta memiliki kinerja yang unggul.Adapun data pendidikan dan kehadiran pengelola keuangan UHO dapat disajikan melalui tabel berikut ini : 
Jurnal Progres Ekonomi Pembangunan (JPEP)

Volume 4, Nomor 1 (2), Tahun 2019

Page: $36-44$

e-ISSN: 2052-5171

http://ojs.uho.ac.id/index.php/JPEP

memperkuatpengaruh prilaku kerja pegawai dalamkelompok atau organisasi. Apabila disiplindapat dilaksanakan dengan baik serta tidakmenunda waktu maka masalah kinerja tidakdibiarkan menjadi parah, dan kemungkinanmasalah yang terjadi dapat diatasi secaratepat dan mudah".

\section{METODE PENELITIAN}

Populasi dalam penelitian ini adalah pengelola keuangan di UHO yang berjumlah 105 Orang.Metode Penentuan sampel menggunakan metode sensus yakni mengambil keseluruhan dari jumlah populasi yang ada yaitu 105 sampel. Jenis data dalam penelitian ini adalah data primer dan sekunder. Pengumpulan data dalam penelitian ini dilakukan dengan melakukan survey lapangan yaitu dengan penyebaran kuisioner. Dalam penelitian ini penulis menggunakan alat analisis regresi linier berganda diolah melalui software SPSS versi 23.0 for Windows. Adapun Hipotesis dari penelitian ini adalah sebagai berikut:

$\mathrm{H}_{1}$ : Pendidikan dan Pelatihan Berpengaruh Positif Signifikan terhadap Kinerja
Pengelola Keuangan.

$\mathrm{H}_{2}$ : Pengalaman Kerja Berpengaruh Positif Signifikan terhadap Kinerja Pengelola Keuangan.

$\mathrm{H}_{3}$ : Disiplin Kerja Berpengaruh Positif Signifikan terhadap Kinerja Pengelola Keuangan.

\section{HASIL DAN PEMBAHASAN}

\subsection{Hasil Penelitian}

\section{Uji Analisis Faktor}

Uji analisis faktor merupakan uji yang digunakan untuk melihat faktor mana dari indikator-indikator yang ada pada seluruh variabel tersebut yang dominan mempengaruhi terbentuknya variabel tersebut. Berdasarkan hasil uji Factor analysis dengan mengikutsertakan uji Kayser-Meyer-Olkin Measure ofSampling Adequency (KMO-MSA) terhadap indikator-indikator dari variabel. Adapun hasil analisis faktor dapat dilihat pada table berikut.

Tabel 2.

Rekapitulasi Analisis Perbandingan Hasil Uji Faktor dan Rata-rata Jawaban Responden

\begin{tabular}{|c|c|c|c|c|c|c|}
\hline No. & Variabel & Indikator & Mean & $P C A$ & $\begin{array}{l}\text { KMO } \\
\text { MSA }\end{array}$ & Sig \\
\hline \multirow{4}{*}{1} & \multirow{4}{*}{$\begin{array}{c}\text { Pendidikan } \\
\text { dan } \\
\text { Pelatihan } \\
\left(\mathrm{X}_{1}\right)\end{array}$} & Materi Yang Diajarkan & 3,81 & 0,744 & \multirow{4}{*}{0,799} & \multirow{4}{*}{0,000} \\
\hline & & Metode Yang Digunakan & 3,76 & 0,751 & & \\
\hline & & Sarana/Fasilitas Pendukung & 3,70 & 0,661 & & \\
\hline & & Kemampuan Instruktur & 3,80 & 0,753 & & \\
\hline \multirow{4}{*}{2} & \multirow{4}{*}{$\begin{array}{c}\text { Pengalaman } \\
\text { Kerja } \\
\left(\mathrm{X}_{2}\right)\end{array}$} & Lama Waktu / Masa Kerja & 4,20 & 0,610 & \multirow{3}{*}{0,705} & \multirow{3}{*}{0,000} \\
\hline & & $\begin{array}{l}\text { Penguasaan terhadap } \\
\text { Pekerjaan dan Peralatan }\end{array}$ & 4,12 & 0,780 & & \\
\hline & & Berani Mengambil Risiko & 4,15 & 0,500 & & \\
\hline & & $\begin{array}{l}\text { Mampu Menghadapi } \\
\text { Tantangan }\end{array}$ & 4,20 & 0,542 & & \\
\hline \multirow{3}{*}{3} & \multirow{3}{*}{$\begin{array}{c}\text { Disiplin } \\
\text { Kerja } \\
\left(\mathrm{X}_{3}\right)\end{array}$} & Displin Waktu & 4,07 & 0,386 & \multirow{3}{*}{0,566} & \multirow{3}{*}{0,000} \\
\hline & & Disiplin Moral & 4,25 & 0,516 & & \\
\hline & & Disiplin Administratif & 4,20 & 0,661 & & \\
\hline \multirow{3}{*}{4} & \multirow{3}{*}{$\begin{array}{c}\text { Kinerja } \\
\text { Pengelola } \\
\text { Keuangan } \\
\text { (Y) }\end{array}$} & Kuantitas Kerja & 4,03 & 0,651 & \multirow{3}{*}{0,668} & \multirow{3}{*}{0,000} \\
\hline & & Kualitas & 3,95 & 0,676 & & \\
\hline & & Ketepatan Waktu & 3,68 & 0,576 & & \\
\hline
\end{tabular}

Sumber : Data Primer Diolah, 2018 
Jurnal Progres Ekonomi Pembangunan (JPEP)

Volume 4, Nomor 1 (2), Tahun 2019

Page: $36-44$

e-ISSN: 2052-5171

http://ojs.uho.ac.id/index.php/JPEP

Besar Adjusted $\mathrm{R}^{2}$ ( $R$-Square) pada tabel diatas adalah 0,493 atau $49,3 \%$. Hal ini menunjukkan bahwa 49,3\% variabelKinerja Pengelola Keuangan (Y) dapat dijelaskan oleh variabel Pendidikan dan Pelatihan $\left(\mathrm{X}_{1}\right)$, Pengalaman Kerja $\left(\mathrm{X}_{2}\right)$ dan Displin $\mathrm{Kerja}\left(\mathrm{X}_{3}\right)$ sedangkan sisanya sebesar 50,7\% dijelaskan oleh variabel lain yang tidak dijelaskan dalam penelitian ini.

Berdasarkan hasil uji hipotesis variabel Pendidikan dan Pelatihan $\left(\mathrm{X}_{1}\right)$ diperoleh nilai $\mathrm{t}_{\text {hitung }}$ sebesar 5,693. Jika dibandingkan dengan nilai $t_{\text {tabel }}$ sebesar 1,983 pada taraf signifikansi 0,05 . Artinya bahwa hipotesis 1diterima, ini berarti Pendidikan dan Pelatihan $\left(\mathrm{X}_{1}\right)$ berpengaruh positif terhadap Kinerja Pengelola Keuangan (Y) dengan nilai koefesien korelasi ${ }^{\circledR}$ sebesar 0,480 , artinya nilai koefesien korelasibernilai positif maka dapat dinyatakan bahwa variabel pendidikan dan pelatihan $\left(\mathrm{X}_{1}\right)$ berpengaruh signifikan terhadap Kinerja Pengelola Keuangan (Y).

Hasil Uji Hipotesis (Uji Simultan dan Uji Parsial) Tabel 3.

Hasil Uji Hipotesis

\begin{tabular}{|l|c|c|c|c|c|}
\hline \multirow{2}{*}{ Variabel } & \multicolumn{2}{|c|}{ Nilai t } & \multirow{2}{*}{ Koef. } & Sig. & Keterangan \\
\cline { 2 - 5 } & $\mathbf{t}_{\text {hitung }}$ & $\mathbf{t}_{\text {tabel }}$ & & & \\
\hline $\begin{array}{l}\text { Pendidikan dan } \\
\text { Pelatihan }\end{array}$ & 5,693 & & 0,480 & 0,000 & $\mathrm{H}_{1}$ Diterima \\
\hline Pengalaman Kerja & 1,577 & \multirow{2}{*}{1,983} & 0,155 & 0,118 & $\mathrm{H}_{2}$ Ditolak \\
\hline Disiplin Kerja & 2,193 & & 0,211 & 0,031 & $\mathrm{H}_{3}$ Diterima \\
\hline F & 32,776 & & & \\
Sig F & 0,000 & & & \\
Adj. R Square & 0,493 & & & \\
\hline
\end{tabular}

Sumber: Data primer diolah (2018)

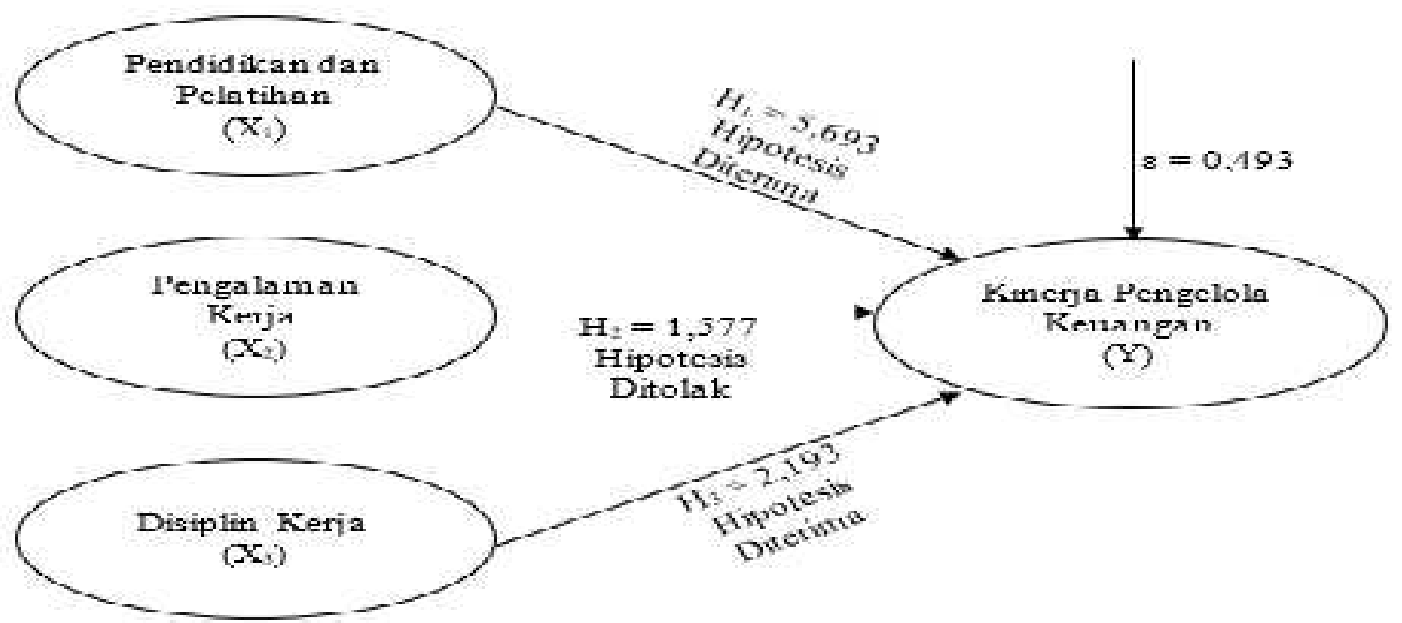

Feterangan :

$X$ : Varnbclicbas

Y - Variabe1 Terikat

\section{Skema 1. Hasil Analisis Penelitian}

Nilai $t_{\text {hitung }}$ Pengalaman Kerja $\left(X_{2}\right)$ diperoleh sebesar 1,577 dan nilai $t_{\text {tabel }}$ sebesar 1,983 pada taraf signifikansi 0,05 . Artinya bahwa hipotesis 2 ditolak ini berarti Pengalaman Kerja $\left(\mathrm{X}_{2}\right)$ tidak berpengaruh terhadap Kinerja Pengelola Keuangan (Y), dengan nilai koefesien korelasi 
Jurnal Progres Ekonomi Pembangunan (JPEP)

Volume 4, Nomor 1 (2), Tahun 2019

Page: $36-44$

http://ojs.uho.ac.id/index.php/JPEP

sebesar 0,155 artinya nilai koefesien korelasi ${ }^{\circledR}$ bernilai positif maka dapat dinyatakan bahwa variabel Pengalaman Kerja $\left(\mathrm{X}_{2}\right)$ tidak berpengaruh signifikan terhadap Kinerja Pengelola Keuangan (Y).

Nilai $t_{\text {hitung }}$ variabel Displin Kerja $\left(X_{3}\right)$ diperoleh sebesar 2,193. Jika dibandingkan dengan nilai $t_{\text {tabel }}$ sebesar 1,983 pada taraf signifikansi 0,05 . Artinya bahwa hipotesis 3 diterima, ini berarti Displin $\operatorname{Kerja}\left(\mathrm{X}_{3}\right)$ berpengaruh terhadap Kinerja Pengelola Keuangan (Y), dengan nilai koefesien korelasi sebesar 0,211, artinya nilai koefesien korelasi ${ }^{\circledR}$ bernilai positif maka dapat dinyatakan bahwa variabel Displin Kerja $\left(\mathrm{X}_{3}\right)$ berpengaruh signifikan terhadap Kinerja Pengelola Keuangan (Y).

\subsection{Pembahasan}

Pengaruh Pendidikan dan Pelatihan terhadap Kinerja Pengelola Keuangan di Universitas Halu Oleo

Hasil uji hipotesis pendidikan dan pelatihan berpengaruh signifikan terhadap kinerja pengelola keuangan di UHO diterima. Pernyataan ini didukung dengan hasil pengujian hipotesis pertama, diperoleh nilai $t_{\text {hitung }}$ sebesar 5,693> $\mathrm{t}_{\text {tabel }}$ sebesar 1,983 dan memiliki nilai signifikansi sebesar $0,000<0,05$. Hal ini menunjukkan bahwa pendidikan dan pelatihan merupakan variabel penjelas kinerja pengelola keuangan di UHO. Temuan tersebut mengindikasikan bahwa apabila seorang pengelola keuangan banyak mengikuti pendidikan dan pelatihan maka kinerjanya akan meningkat.

Sesuai hasil analisis jawaban responden terhadap variabel pendidikan dan pelatihan dengan melihat nilai PCA (Principal Component Analysis) menunjukkan bahwa kemampuan instruktur merupakan indikator yang paling dominan mendeskripsikan variabel pendidikan dan pelatihan disusul indikator metode yang digunakan. Artinya keterampilan instruktur dalam menyampaikan materi mudah dimengerti oleh pengelola keuangan di Universitas Halu Oleo sehingga memotivasi mereka dalam mempraktikan materi yang diajarkan didalam proses bekerja. Melihat nilai mean, indikator yang paling dominan mendeskripsikan variabel pendidikan dan pelatihan adalah indikator materi yang diajarkan disusul indikator kemampuan instruktur. Artinya bahwa kemampuan instruktur melalui pendidikan dan pelatihan adalah berperan penting dalam meningkatkan pengetahuan mereka mengenai materi yang diberikan serta dapat menerapkan ataupun menunjang dalam penyelesaian pekerjaannya.

Hasil analisis statistik deskriptif menunujukkan persepsi responden terhadap variabel pendidikan dan pelatihan sudah baik dengan skor $765,33 \%$. Hal ini menunjukkan bahwa pendidikan dan pelatihan yang dimiliki oleh kinerja pengelola keuangan di UHO sudah baik yang terbentuk dari materi yang diajarkan, metode yang digunakan, sarana/fasilitas pendukung, dan kemampuan instruktur. Kegiatan pendidikan diberikan untuk membantu pegawai mengembangkan kapasitasnya/pengetahuan yang dimilikinya sehingga pegawai dapat bekerja lebih baik dalam meningkatkan kinerja untuk mencapai tujuan dari organisasi di masa yang akan datang.

Temuan penelitian ini sesuai dengan teori yang dikemukana oleh Rachmawati (2008:13) menjelaskan pendidikan dan pelatihan bagi pegawai merupakan sebuah proses mengajarkan pengetahuan, keahlian tertentu, sikap dan mampu melaksanakan tanggung jawab yang diberikan. Pendidikan dan pelatihan menjadi begitu penting untuk diterapkan dalam mengelola keuangan karena akan memberi pengaruh pada peningkatan kinerja sehingga untuk melaksanakan tugas dan wewenang tidak menemukan hambatan.

Hasil penelitian ini mengkonfirmasi Dartha (2010), Turere (2013), Ningsih (2017), Nurdin (2012) bahwa pegawai yang memiliki pendidikan yang tinggi memiliki hasil kerja yang melampaui tugas pokoknya. Hasil penelitian ini tidak mengkonfimasi penelitian Pakpahan (2015) dan Kowaas (2016) yang menemukan bahwa pendidikan tidak berpengaruh secara signifikan terhadap kinerja karyawan.

Pengaruh Pengalaman Kerja terhadap Kinerja Pengelola Keuangan di Universitas Halu Oleo

Hasil uji hipotesis yang menyatakan bahwa pengalaman kerja berpengaruh signifikan terhadap kinerja pengelola keuangan di UHO ditolak. Pernyataan ini didukung dengan hasil pengujian hipotesis kedua, diperoleh nilai $t_{\text {hitung }}$ 
Jurnal Progres Ekonomi Pembangunan (JPEP)

Volume 4, Nomor 1 (2), Tahun 2019

Page: $36-44$

http://ojs.uho.ac.id/index.php/JPEP

sebesar $1,577<\mathrm{t}_{\text {tabel }} 1,983$ dan memiliki nilai sebesar $0,118>0,05$ yang berarti bahwa pengalaman kerja tidak berpengaruh dan tidak signifikan terhadap kinerja pengelola keuangan. Hasil tersebut menunjukkan bahwa pengalaman kerja tidak memiliki pengaruh terhadap kinerja pengelola keuangan di UHO. Sesuai hasil analisis jawaban responden terhadap variabel pengalaman kerja dengan melihat nilai PCA(Principal Component Analysis) menunjukkan bahwa penguasaan terhadap pekerjaan dan peralatan merupakan indikator yang paling dominan mendeskripsikan variabel pengalaman kerja disusul indikator lama waktu/masa kerja sedangkan melihat nilai mean, indikator yang paling dominan mendeskripsikan variabel pengalaman kerja adalah indikator mampu menghadapi tantangan disusul indikator penguasaan terhadap pekerjaan dan peralatan. Artinya bahwa yang seharusnya yang dilakukan oleh pengelola keuangan adalah meningkatkan penguasaan terhadap pekerjaan dan peralatan terkait dengan dalam menatausahakan pertanggungjawaban keuangan dan lamanya bekerja/masa kerja sebagai pengelola keuangan dapat membantu meningkatkan kinerja serta dapat membantu memahami dan menyelesaikan tugastugas dengan baik sesuai ketentuan.

Hasil analisis statistik deskriptif menunujukkan persepsi responden mengenai pengalaman kerja sudah sangat baik dengan skor $83,33 \%$. Hal ini menunjukkan bahwa sebagian besar pengelola keuangan memiliki pengalaman kerja yang sangat baik dalam melaksanakan tugasnya. Ketidaksignifikasian hasil penelitian ini menunjukkan bahwa pengalaman kerja belum menjadi pengaruh bagi kinerja pengelola keuangan di Universitas Halu Oleo. Hal ini disebabkan oleh persepsi responden berbeda-beda dalam menanggapi pernyataan-pernyataan dalam kuisioner pengalaman kerja. Terdapat 127 (seratus dua puluh tujuh) tanggapan netral untuk pernyataan pada semua indikator pengalaman kerja. Indikator yang paling banyak mendapat tanggapan netral adalah berani mengambil risiko. Para pengelola keuangan di UHOmasih ragu dalam membuat keputusan yang berhubungan dengan pekerjaannya. Mereka belum bisa memilih tindakan yang tepat dalam menunjang proses pelaksanaan tugas dalam pekerjaan dan belum memahami konsekuensi keputusan yang diambil sesuai dengan tugas dan tanggung jawabnya.

Temuan ini sesuai dengan teori yang dikemukakan oleh Foster (2001) dan Sutrisno (2009) yang membagi pengalaman kerja kedalam 4 (empat) faktor, yaitu lama waktu atau masa kerja, penguasaan terhadap pekerjaan dan peralatan, berani mengambil resiko, dan mampu menghadapi tantangan dengan penuh tanggung jawab. Sebagian besar pengelola keuangan di UHOcenderung lebih memiliki banyak pengalaman dalam penguasaan pekerjaan penatausaahan dan penyusunan laporan keuangan.

Hasil penelitian ini mengkonfirmasi Septiani (2015) bahwa pengalaman kerja tidak berpengaruh secara signifikan terhadap kinerja karyawan. Hasil penelitian ini tidak mengkonfimasi penelitian Pakpahan (2015), Aristarini(2015) serta Hani'ah (2015) bahwa pengalaman kerja berpengaruh positif dan signifikan terhadap kinerja pegawai.

Pengaruh Disiplin Kerja terhadap Kinerja Pengelola Keuangan di Universitas Halu Oleo

Hasil uji hipotesis yang menyatakan bahwa disiplin kerja berpengaruh signifikan terhadap kinerja pengelola keuangan di UHOditerima. Pernyataan ini didukung dengan hasil pengujian nilai $t_{\text {hitung }}$ sebesar $2,193>t_{\text {tabel }} 1,983$ dan memiliki nilai signifikansi sebesar $0,031<0,05$. Hal ini menunjukkan bahwa semakin tinggi disiplin kerja yang dimiliki oleh seorang pengelola keuangan maka semakin tinggi pula kinerjanya.

Sesuai hasil analisis jawaban responden terhadap variabel disiplin kerja dengan melihat nilai PCA(Principal Component Analysis) menunjukkan bahwa indikator disiplin administratif merupakan indikator yang paling dominan mendeskripsikan variabel disiplin kerja disusul indikator disiplin moral sedangkan melihat nilai mean, indikator yang paling dominan mendeskripsikan variabel disiplin kerja adalah indikator displin moral disusul indikator disiplin administratif. Artinya bahwa yang seharusnya menjadi perhatian bagi pengelola keuangan di UHOadalah pengelola keuangan 
Jurnal Progres Ekonomi Pembangunan (JPEP)

Volume 4, Nomor 1 (2), Tahun 2019

Page: $36-44$

http://ojs.uho.ac.id/index.php/JPEP

mengetahui sepenuhnya peraturan yang telah ditetapkan dan dituntun untuk melaksanakan pekerjaan sesuai dengan prosedur/peraturan yang ditetapkan namun pengelola keuangan di UHOlebih mengutamakan menyelesaikan pekerjaan dengan penuh tanggungjawab serta menjaga sikap yang baik didalam lingkungan UHO yang merupakan hal yang paling penting dalam meningkatkan disiplin kerja pada pelaksanaan pekerjaannya.

Lebih lanjut para pengelola keuangan di UHOtelah memahami dan melaksanakan peraturan yang telah ditetapkan oleh UHO, terutama yang berkaitan dengan penggunaan seragam dan atributnya karena hal ini menunjukkan jati diri seorang pengelola keuangan. Disiplin administratif pegawai dalam menjalankan tugas pengelolaan keuangan tidak dapat ditawar-tawar lagi karena hal ini menyangkut prosedur kerja yang telah ditetapkan sehingga tidak dapat dilanggar dan bahkan diabaikan. Prosedur kerja harus dipahami oleh seluruh pengelola keuangan di Universitas Halu Oleo. Dengan dipahaminya prosedur kerja maka proses pelaksanaan pekerjaan dapat berjalan sesuai dengan koridor yang telah ditetapkan.

Hasil analisis statistik deskriptif menunujukkan persepsi responden terhadap variabel disiplin kerja sudah sangat baik dengan skor 83,21\%. Hal ini menunjukkan bahwa disiplin kerja yang dimiliki oleh kinerja pengelola keuangan di UHOsudah sangat baik yang terbentuk dari displin waktu, disiplin moral, dan disiplin administratif. Sebagai seorang pengelola keuangan tentunya sudah memahami apa yang menjadi tugas pokoknya. Pegawai yang memiliki kedisiplinan kerja yang tinggi tentunya paham dengan benar bahwa tugas yang menjadi tanggungjawabnya harus dapat dijalankan dengan baik dan tepat waktu.

Temuan penelitian ini sesuai dengan teori disiplin kerja yang dikemukakan oleh Mondy (1996 : 36) bahwa tindakan disiplin yang efektif akan mendorong individu untuk meningkatkan kinerja yang menguntungkan individu tersebut dan tentunya juga organisasi.
Hasil penelitian ini mengkonfirmasi penelitian Suardi (2014), Sartika (2015) serta Kasenda (2016) tentang pengaruh disiplin kerja terhadap kinerja pegawai yang menemukan bahwa disiplin kerja berpengaruh positif signifikan terhadap kinerja pegawai. Hasil penelitian ini tidak mengkonfimasi penelitian Setiawan (2013) dan Kowas (2016) yang menemukan bahwa disiplin kerja tidak berpengaruh siginifikan terhadap kinerja pegawai.

\section{KESIMPULAN}

Berdasarkan hasil penelitian dan pembahasan yang telah diuraikan, maka simpulan dalam penelitian ini adalah sebagai berikut:

(1) Pendidikan dan pelatihan berpengaruh signifikan terhadap kinerja pengelola keuangan di UHO., (2) Pengalaman kerja tidak berpengaruh signifikan terhadap kinerja pengelola keuangan di UHO, (3) Disiplin kerja berpengaruh signifikan terhadap kinerja pengelola keuangan di UHO.

\section{DAFTAR PUSTAKA}

Aristarini Luh, I Ketut Kirya, Ni Nyoman Yulianthini. 2014. Pengaruh Pengalaman Kerja, Kompetensi Sosial dan Motivasi Kerja Terhadap Kinerja Karyawan Pada Bagian Pemasaran PT. Adira Finace Singaraja. Universitas Pendidikan Ganesha. Bali.

Biro Perencanaan dan Penganggaran. 2017. Laporan Akuntanbilitas Kinerja Instansi Pemerintah (LAKIP) Universitas Halu Oleo Tahun 2016. Kendari

Dartha. I Ketut. 2010. Pengaruh Pendidikan dan Pelatihan (Diklat) Terhadap Kinerja Pegawai Negeri Sipil Pada Sekretariat Daerah Kota Malang. Jurnal Ekonomi Modernisasi. Fakultas Ekonomi. Universitas Kanjuruhan. Malang.

Foster, B.S., R. Karen. 2001. Pembinaan Untuk Meningkatkan Kinerja Karyawan. PPM. Jakarta.

Hani'ah, Ririn Siswa. 2015. Determinasi Kinerja Pengelola Keuangan di Tingkat SMA/SMK Negeri Se-Kota Madiun. Universitas Sebelas Maret. Surakarta.

Corresponding Author: Sri Wahyuni Saleh | 43 
Jurnal Progres Ekonomi Pembangunan (JPEP)

Volume 4, Nomor 1 (2), Tahun 2019

Page: $36-44$

http://ojs.uho.ac.id/index.php/JPEP

Kasenda, R.T. Deborah, Rita, Lucky. 2016. Pengaruh Pengembangan Karir dan Disiplin Kerja terhadap Kinerja Karyawan Pada PT. Bank Sulutgo Cabang Kawangkoan. Jurnal Berkala Ilmiah Efisiensi.Universitas Sam Ratulangi. Manado.

Kowaas Meisy Pramasela, Jantje L. Sepang, Rita N. Taroreh. 2016. Pengaruh Pendidikan Pelatihan dan Disiplin Kerja Terhadap Kinerja Pegawai Pada Badan Penanggulangan Bencana Daerah Provinsi Sulawesi Utara. Universitas Sam Ratulangi. Manado.

Leiden, Robert. 2001. Managing Individual Performance In Works Groups. Journal Human Resources Management Vol 40.

Mondy, R. W. dan Noe R. M. 1996. Personnel : The Management of Human Resources, Allyn and Bacon Inc., Boston.

Ningsih. Citra Rahayu. 2017. Pengaruh Pendidikan dan Pelatihan Terhadap Kompetensi Karyawan PT. Antam Pomalaa. Fakultas Ekonomi dan Bisnis. Universitas Halu Oleo. Kendari.

Nurdin. 2012. Pengaruh Tingkat Pendidikan (Pelatihan) dan Disiplin Kerja terhadap Kinerja Karyawan Yayasan MH. Thamrin. Sekolah Tinggi Ilmu Ekonomi Sailendra.

Pakpahan Moben, Sastra Tamami. 2015. Pengaruh Pendidikan dan Pengalaman Kerja Terhadap Kinerja Karyawan PT. Labtech Penta Internasional Batam. Universitas Riau Kepulauan. Riau Kepulauan.

Peraturan Pemerintah Republik Indonesia Nomor 23 Tahun 2005 tentang Pengelolaan Keuangan Badan Layanan Umum.

Peraturan Menteri Dalam Negeri Nomor 61 tahun 2007 tentang Pedoman Teknis Pengelolaan Keuangan Badan Layanan Umum.

Sartika Amwiarni. 2015. Pengaruh Kompetensi, Disiplin Kerja dan Pengalaman Kerja Terhadap Kinerja Pegawai Dinas Pendapatan, Pengelolaan Keuangan dan Aset Daerah Kota Palu. Universitas Tadulako. Palu.

Septiani Virgina Maulidiah. 2015. Pengaruh Pelatihan, Pengalaman Kerja dan Promosi Jabatan Terhadap Kinerja Karyawan Pada
Badan Pemeriksa Keuangan Republik Indonesia Perwakilan Sulawesi Utara ISSN 2303-11, Jurnal EMBA Vol. 3 No. 3 Sept. 2015. Universitas Sam Ratulangi. Manado.

Setiawan Agung. 2013. Pengaruh Disiplin Kerja dan Motivasi Terhadap Kinerja Karyawan pada Rumah Sakit Umum Daerah Kanjuruhan Malang Jurnal Ilmu Manajemen Volume 1 Nomor 4 Juli 2013. Universitas Negeri Surabaya. Surabaya.

Soestrisno, P.H. 1992. Kapita Selekta Ekonomi (Suatu Studi). Edisi II. Yogyakarta: Penerbit Andi Offset.

Suardi, Anto Tulim, Suharsil. 2014. Pengaruh disiplin kerja, pendidikan dan pelatihan terhadap kinerja pegawai pada PT Kertas Kraft Aceh (persero) ISSN : 1978-6603. STMIK Triguna Dharma.

Rachmawati, Ike Kusdyah. 2008. Manajemen Sumber Daya Manusia, Penerbit. ANDI, Yogyakarta.

Robbins, Stephen P. dan Judge, Timothy A. 2006. Perilaku Organisasi Edisi ke-10, Jakarta: Salemba Empat.

Turere. Verra Nitta. 2013. Pengaruh Pendidikan dan Pelatihan Terhadap Peningkatan Kinerja Karyawan Pada Balai Pelatihan Teknis Pertanian Kalasey. ISSN 23031174. Fakultas Ekonomi Reguler Sore. Universitas Sam Ratulangi. Manado.

Veithzal, Rivai. 2004. Manajemen Sumber Daya Manusia untuk Perusahaan Cetakan Pertama. Jakarta : PT Rajagrafindo Persada, Jakarta. 